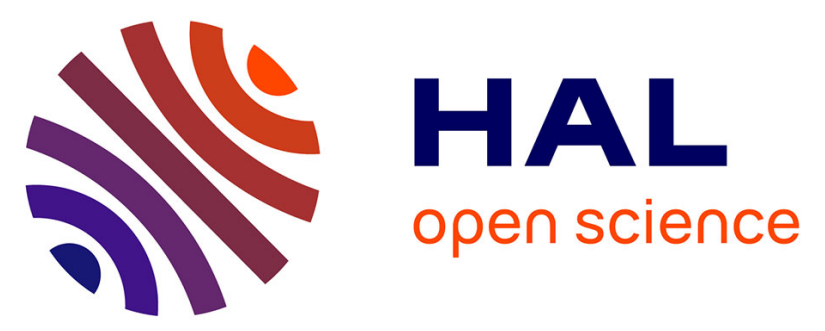

\title{
The pre-Columbian site of Roseau (Guadeloupe, F. W. I.): intra-site chronological variability of the subsistence strategies in a Late Ceramic archaeological vertebrate assemblage
}

Corentin Bochaton, Brice Ephrem, Benoît Bérard, David Cochard, Monica

Gala, Kristine Korzow Richter, Alice Le Lay, Sylvain Renou, Arnaud Lenoble

\section{To cite this version:}

Corentin Bochaton, Brice Ephrem, Benoît Bérard, David Cochard, Monica Gala, et al.. The preColumbian site of Roseau (Guadeloupe, F. W. I.): intra-site chronological variability of the subsistence strategies in a Late Ceramic archaeological vertebrate assemblage. Archaeological and Anthropological Sciences, 2021, 13 (1), 10.1007/s12520-020-01246-4 . hal-03102150

\author{
HAL Id: hal-03102150 \\ https://hal.science/hal-03102150
}

Submitted on 7 Jan 2021

HAL is a multi-disciplinary open access archive for the deposit and dissemination of scientific research documents, whether they are published or not. The documents may come from teaching and research institutions in France or abroad, or from public or private research centers.
L'archive ouverte pluridisciplinaire HAL, est destinée au dépôt et à la diffusion de documents scientifiques de niveau recherche, publiés ou non, émanant des établissements d'enseignement et de recherche français ou étrangers, des laboratoires publics ou privés. 
The pre-Columbian site of Roseau (Guadeloupe, F. W. I.): intra-site chronological variability of the subsistence strategies in a Late Ceramic archaeological vertebrate assemblage

Corentin Bochaton ${ }^{1,2, *}$, Brice Ephrem ${ }^{3}$, Benoit Bérard ${ }^{4}$, David Cochard ${ }^{1}$, Monica Gala ${ }^{1}$, Kristine Korzow Richter $^{2}$, Alice Le Lay ${ }^{4}$, Sylvain Renou ${ }^{1}$, Arnaud Lenoble ${ }^{1}$

${ }^{1}$ PACEA - UMR CNRS 5199, Université de Bordeaux, 33615 Pessac, France

${ }^{2}$ Max Planck Institute for the Science of Human History, Department of Archaeology, Kahlaische Straße 10, 07745 Jena, Germany.

${ }^{3}$ AUSONIUS - UMR CNRS 5607, Université Bordeaux Montaigne, 33607 Pessac, France.

${ }^{4}$ Université des Antilles, laboratoire AIHP-GEODE Caraïbe (EA 929), Campus universitaire de Schœlcher, BP 7209, 97275 Schœlcher cedex.

*Coresponding author: corentin.bochaton@u-bordeaux.fr

\begin{abstract}
Evidence for chronological change in intra-site subsistence strategies is very rare in the Amerindian record of the Lesser Antilles. The study of the vertebrate assemblage from the archaeological site of Roseau in the Guadeloupe Islands underlines the complexity and variability of Ceramic Age Amerindian subsistence behavior. This study establishes a more precise chronology of the previously identified strata of the site, and demonstrates that the Contact period was only represented by rare archaeological artifacts dispersed in the stratigraphy. The results from this assemblage indicate that the earlier occupations of the site exhibit a more intensive exploitation of aquatic vertebrate resources compared to later occupations, which have a larger focus on terrestrial fauna, especially rodents and iguanas. This unusual pattern highlights how subsistence behaviors in the Lesser Antilles during the Late and Final Ceramic periods were highly variable. This new evidence of strong inter-site variability shows that the behaviors of Amerindians are not only dependent of large scale environmental conditions but are also influenced by more complex socio-cultural and local environmental parameters.
\end{abstract}

Keywords: Amerindian, Caribbean, Island, Subsistence, Tropics, Zooarchaeology

\title{
Declarations
}

\section{Funding}

This study was funded by the FEDER program 2016-2020 "Ecosystème insulaire tropical, réponse de la faune vertebrae terrestre à 6000 ans d'anthropisation de la Guadeloupe" (ECSIT), operated by the CNRS and funded by a European PO-FEDER 2014-2020 grant (grant $\mathrm{n}^{\circ}$ 2016-FED-503), the Guadeloupe Regional Council, and the DAC of Guadeloupe. The palaeoproteomic analysis was funded by the Max Planck Society.

Conflicts of interest/Competing interests

The authors declare they have no conflicts of interest or competing interests.

\section{Availability of data and material}

All the data used in this study are available in the text of the paper and in the supplementary materials. The studied archaeological material is stored in a public repository in the Service Régional de l'Archéologie of Guadeloupe (Le Moule, Guadeloupe).

\section{Code availability}

Not applicable

Authors' contributions

A.L. and C.B. designed the study, C. B. and A. L. drafted the paper, A. L. performed the chronological and stratigraphic analysis of the deposit, A. L. L. and B. B. performed the ceramic analysis, B. E. studied the fish remains, C. B. studied the reptile remains, M. G. studied the bird remains, D. C. studied the small mammal remains, C. B., D. C. and S. R. studied the large mammal remains, K. K. R. performed the paleoproteomic analysis, and all authors contributed to scientific and editorial input in the final version of the paper.

\section{Acknowledgments}

We are grateful to Gérard Richard who provided very useful published and unpublished information regarding the archeological context of the Roseau material. We are also grateful to the two anonymous reviewers whose comments helped us to improve the quality of this paper. This study was funded by the FEDER program 20162020 'Ecosystème insulaire tropical, réponse de la faune vertebrae terrestre à 6000 ans d'anthropisation de la Guadeloupe" (ECSIT), operated by the CNRS and funded by a European PO-FEDER 2014-2020 grant (grant $\mathrm{n}^{\circ}$ 2016-FED-503), the Guadeloupe Regional Council, and the DAC of Guadeloupe. We are also grateful to JeanBaptiste Mallye, Stéphane Rottier, and Violaine Palacio for their assistance in the identification and digitization of the large mammal bones selected for ZooMS analyses. We also thank Véronique Laroulandie and David 
Steadman for their advice regarding the identification of select bird remains, as well as C. Lefèvre, M. Florence, and C. Milensky for enabling the access to modern bird osteological collections. 


\section{Introduction}

Subsistence strategies of archaeological populations reflect the complex interaction between environmental pressures, demographic contexts, and cultural choices of human groups (Politis and Saunders 2002). However, it is often challenging to separate the influence of different factors on choices made by humans when exploiting the resources in a specific environment, as it requires a good understanding of the contemporaneous natural environments and socio-economic characteristics of archaeological populations. Insular contexts represent a good opportunity for such studies as they provide a context where it is easier to evaluate the availability of the limited resources accessible to human groups and the corresponding cultural choices. The Caribbean islands have been the objects of numerous zooarchaeological studies but extensive data are still only available on a limited sample of islands (e. g. deFrance, 1990; Newsom and Wing, 2004; Grouard, 2007; LeFebvre and Giovas, 2009). Currently available data have permitted the proposal of diverse hypotheses regarding the subsistence behaviors of the successive Amerindian inhabitants of the Caribbean Lesser Antilles. However, as research grows in this region more evidence emerges of chronological and geographical variability in human subsistence behaviors.

The first human populations to colonize these islands (between 5800 and 2500 cal years B.P. (Archaic Age)) were non-ceramic populations (Siegel et al. 2015; Bérard 2019; Napolitano et al. 2019). They were later replaced around ca. $400 \mathrm{BC}$ by ceramic populations originating from South America the first of which (Early and Middle Ceramic) are from the Saladoid cultural current (see Bérard, 2019 for more detailed subdivisions). Although we now have archaeological evidence that these Amerindian populations occupied nearly all of the Lesser Antillean islands, the general colonization pattern is subject to much chronological variability at the regional scale (Giovas and Fitzpatrick 2014). Differences on size and geology between islands create a diversity of natural habitats and resources at an inter-island level which allows for the study of Amerindians subsistence behaviors in different geographical, ecological, and chronological contexts.

Several studies have tried to approach these questions and to establish regional models regarding Amerindian exploitation of their environment in the Lesser Antilles. The first regional zooarchaeological studies initially observed a shift from terrestrial to aquatic resources during the Ceramic period. This was first explained as population replacement where Early Ceramic populations that consumed terrestrial crabs were replaced by later populations that consumed marine shellfish (Rainey 1940). Subsequent research identified other possible explanations to explain this shift of subsistence behaviors, including climate change, overexploitation of terrestrial crabs, and diet breadth expansion following population growth (Goodwin 1979; Carbone 1980; Keegan 1989). More complex hypotheses have also been proposed which integrate cultural choices with island ecology. As the evolution of Amerindian diet from terrestrial to aquatic resources is also observed in vertebrate bone remains, some researchers have proposed that the earlier populations tried to replicate their continental way of life by including a significant amount of terrestrial animals in their diet. In contrast, the populations (see Bérard, 2019 for details) that occupied the region during the Late and Final Ceramic periods developed strategies that focused primarily on the more plentiful, marine resources (Jones 1985; Wing 1989).

A second complex hypothesis for the change in subsistence strategies through time was the exhaustion of natural resources, possibly related to a population increase, that may have forced Amerindians to enlarge their diet breadth (Goodwin 1979; Keegan 1989). This was proposed primarily to explain the simultaneous reduction of the mean trophic level of marine resources and the size of fish consumed during the Late Ceramic period in the Virgin Islands (Wing and Wing 2001) and Bahamas (Blick 2007). Although there is a possible global trend for the temporal reduction of the size of archaeological fishes at the regional scale (Grouard et al. 2019), the pattern observed on the Virgin Islands and Bahamas has not been observed on other islands, including Carriacou (Giovas 2016a), Guadeloupe (Grouard 2001a), and Anguilla (Carder et al. 2007; Allen et al. 2011; Carder and Crock 2012). As more zooarchaeological studies were conducted, both the regional trends and single explanations for subsistence changes have been called into question. The Ceramic Age subsistence strategies have been found to be highly adaptive and diverse (Wing 2001a; Newsom and Wing 2004). The majority of sites report that the consumption of animal protein by Amerindian groups consisted primarily of aquatic resources, including in Archaic Age deposits (Hofman and Hoogland 1999; Newsom and Wing 2004). This result is in accordance with the richness of the Caribbean coral reefs, and the proximity of most sites to the sea. In addition, 
some Ceramic Age assemblages deviate from this trend with a notable consumption of terrestrial animals, for instance: Trants in Montserrat (Reitz 1994), Cayon at St-Kitts (Wing and Scudder 1980), Hope Estate in SaintMartin (Grouard 2004), and Morel in Guadeloupe (Grouard 2007). This absence of archaeological evidence of a chronological evolution from a terrestrial toward a marine diet at the regional scale is also in accordance with isotopic data which suggest that the size and geology of the island (limestone vs. volcanic) has a prominent impact on Amerindian subsistence choices (Stokes 1998).

The reasons for the Amerindian variation in subsistence strategy are therefore presently unclear, especially because there is no longer a clear regional chronological change. An intra-site chronological transition from a dominant exploitation of terrestrial to a dominant exploitation of aquatic resources, or the reverse, has only been observed two times in the Lesser Antilles, at the Indian Creek (Jones 1985), and AR-38/AR-39 (Carlson and Steadman 2009) sites. While similar but more subtle subsistence strategies modifications are suggested by the assemblages of Keldey's Ridge site (Wing 2001a), and possibly Sabazan (Giovas 2016b) although the material is not abundant enough to draw a clear conclusion from the latter. This is problematic as the zooarchaeological study of such assemblages is, along with isotopic study of human remains, the only possible way to emphasis a modification in the behavior of a human group that is potentially independent of environmental modification. In this study, we demonstrate and discuss an additional occurrence of an intra-site chronological transition in this case from a primarily aquatic to a primarily terrestrial subsistence strategy in the Late Ceramic assemblage of Roseau in Guadeloupe. The complete profile of the faunal and ceramic assemblage is described, a series of new radio-carbon dates obtained, and a reinterpretation of the stratigraphy of the site is proposed. The interpretation of this transition in light of the dense paleoenvironmental data available in the Guadeloupe islands is further discussed.

\section{The site of Roseau}

The Guadeloupe Islands are located in the central part of the Lesser Antilles between Dominica and Montserrat (Fig. 1). The oldest archaeological site in these islands is the site Pointe des Pies dating to around 1000 cal. BC, (Richard 1994) but indirect paleoenvironmental evidence indicate that the first human settlements may be as old as 3000 cal. BC (Stouvenot et al. 2014; Siegel et al. 2015). The oldest Ceramic Age site is Morel I, an Early Ceramic site (Huecan Saladoid cultural current) dating to around AD 80 (Clerc 1964; Hofman et al. 1999). More recent archaeological sites dating from the Early to the Final Ceramic periods are numerous in Guadeloupe (Delpuech 2001) but the evidence for Contact period (Cayo cultural current) sites are rare. The Contact period follows the arrival of Columbus in 1493, and ends with the first permanent European settlements in 1635 (Keegan et al. 2013). One of the few sites from this brief period is Roseau on Basse-Terre, the largest island of Guadeloupe. Its name refers to the Roseau beach on which it lies, on the southeastern coast of the Island, $1.5 \mathrm{~km}$ south of the town of Ste Marie (N165'41.988', W61³3'37.292') (Fig. 1-a), in an environment of seasonal evergreen forest, around $2 \mathrm{~km}$ from the lower edge of the windward rainforest (Rousteau et al. 1994).

The site at the beach of Roseau was identified in the 1960s through surface recovery of archaeological remains but was not excavated until 2001 and 2002 by Gérard Richard (Richard 2003). The nearby site at the parking lot of Roseau situated $200 \mathrm{~m}$ south of the beach site was more recently excavated by INRAP but did not provide an assemblage of bone comparable to the one recovered from the beach site (van den Bel et al. 2018). The beach excavation involved several trenches; most of the ceramic material and all of the vertebrate remains were collected in trenches B0-B1-B2 and A0-A1 (Fig. 1-b). A sieving column set in the middle of the B0-B1 trench enabled the recovery of most of the faunal remains. The excavated area was identified as a pit in the form of a ravine, filled with a stratified dump, as demonstrated by the stratigraphy of the trench B0-B2 (Fig. 1-b). The excavation consisted of a trench cut into the upstream portion of the ravine, uncovering infilling to a depth of two meters. Three main layers were identified during the excavation (Fig. 2-a).

The first studies identified the cultural and chronological attributions from the ceramic assemblages and C14 dating of unidentified shells and a human bone (see Sup. Mat. 1). Level 1 was assigned to the Contact period from a calibrated date between 1432 and 1502 AD. This level contained some remarkable finds, such as a manatee bone cup carved with a zoomorphic pattern interpreted as being of Taíno origin. Level 2 was identified as Final Ceramic (Suazan Troumassoid cultural current) from a calibrated date between 1274 and 1367 AD, and 
level 3 was identified as Late Ceramic (Troumassan Troumassoid cultural current) from a calibrated date between 997 and 1090 AD. The surface finds were attributed to a hypothetical level called "0". However, more recent reconsideration of these chronostratigraphic assignations have revealed them to be somewhat artificial. Contextual information from dated samples in the Banadora database (http://www.arar.mom.fr/banadora) indicate that the $\mathrm{C} 14$ dating of level 1 was obtained from a surface remain and that the date for level 3 comes from a bone collected in level 2. In addition, other unpublished dates were obtained immediately following the excavation, and potentially provide a more complex chronological pattern (Fig. 2-d; Sup. Tab. 1). However the majority of these dates were obtained from shells that were not taxonomically identified, so the possibility that the obtained $\mathrm{C} 14$ ages are older than their actual ages cannot be excluded. Finally, the significant regional variations of the reservoir effect in the Lesser Antilles makes the dates obtained on marine material to be subject to large uncertainties (DiNapoli et al. 2021). As an effect of these numerous issues it was impossible to clearly asses the consistency of the stratigraphy of Roseau on the basis of obtained radio-carbon dates. The first analyses indicated that the site contained material from the Contact period and represented a continuous occupation throughout the whole of Late Ceramic (Troumassoid) period. However, the dating remained poorly resolved, the analysis of the ceramic finds was incomplete, and the study of the faunal assemblage had not yet been carried out. This precluded a clear understanding of the site both in term of chronology and in terms of the behavior of the Amerindian populations.

\section{Materials and methods}

\section{$14 C$ dating and calibration}

In order to improve our understanding of the chronology of the deposit and to test its stratigraphic coherence, we took advantage of twenty new ${ }^{14} \mathrm{C}$ samples obtained during a study on the isotopic profile of rice rat teeth recovered from the site (Goedert et al. 2020). The dates were performed on the dentine of the teeth of single individuals of known species in order to eliminate reservoir and old carbonate effects, in accordance with radiometric hygiene requirements (Napolitano et al. 2019). Eight of the twenty radiocarbon dates are of known stratigraphic origin (Fig. 2-d). The other dates were relevant in the context of the isotopic study and contribute to the overview of the chronology of the site but are not useful for interpreting the discrete strata (Fig. 2-b). An additional date was also performed on one of the human remains sent out for palaeoproteomic analysis..The 14C dates were calibrated using Calib online (Stuiver et al. 2020). Dates obtained from shells were calibrated using the Marine20 curve, and those obtained from rodent dentine with the Intcal20 curve (Reimer et al. 2020). Dates obtained from human remains were calibrated using a mixed Intcal/Marine curve. For all calibrations using the Marine curve, referred to the mean value of the marine reservoir corrections $(\delta \mathrm{R})$ established by for the Caribbean, i.e. $-146+/-114$ (DiNapoli et al. 2021) (but see Sup. Text 1 for details regarding human remains).

\section{Archaeological material recovery}

The faunal and ceramic assemblages were collected both manually and by sieving with a $0.5 \mathrm{~m}^{2}$ sediment column with $2 \mathrm{~mm}$ wide mesh located in the middle of the B0-B1 trench (Richard 2003) (Fig. 1). The full assemblage is composed of 12,899 ceramic remains (286 kg) (Sup. Tab. 2) of which 5,021 (177 kg) have been studied and are presented in the current study. The faunal remains consist of 8,591 studied vertebrate bone, but only 6,533 remains are of known stratigraphic origin and therefore relevant to the discussion of the evolution of subsistence strategies.

\section{Ceramic analysis}

The ceramic series of Roseau was the subject of two as of yet unpublished studies. The first, carried out by Arie Boomert in 2010 and restricted to a qualitative approach, focused on the Cayo remains (Honoré 2013), and a second that was more exhaustive in the form of a Master's dissertation carried out by Alice Le Lay (Le Lay 2013). The ceramic study presented here is a synthesis of the latter study. 
Ceramic remains greater than $3 \mathrm{~cm}$ in length from the three main test pits (A0A1, B0B2 and C0C1) (Fig. 1-b) were analyzed. After initial rapid sorting, a short technological study was performed followed by a morphostylistic analysis. The assemblages from the different strata that were identified during the excavation were compared to create a cultural characterization of the occupation sequence. The morphological analysis of the ceramic remains follows a combination of the main typological nomenclatures commonly used in the Lesser Antilles (Hofman 1993; Bérard 2004; Bonnissent 2008) (see Sup. Fig. 1). The results were compared with various Troumassoid reference collections that are clearly described in the literature: Trou Massé "B" and Micoud in Ste Lucia (McKusick 1960); L'espérance, Paquemar and Macabou in Martinique (Allaire 1977); Spring Bay and Kelbey's Ridge in Saba (Hofman 1993); Mill Reef and Marmora Bay in Antigua (Rouse and Faber Morse 1999); and Baie au Prunes in St. Martin (Bonnissent 2005). Cayo elements were characterized after the pioneering work of Boomert (Boomert 1986) supplemented by more recent contributions (Boomert 2011; Hofman et al. 2019, 2020).

\section{Zooarchaeological analysis}

The study of the different animal taxonomic groups was conducted independently by different specialists sharing a common methodology.

Fish and mammal remains were identified using the comparative collection of the PACEA laboratory (Bordeaux, France). Reptiles were identified using the osteological comparative anatomy collection of the Muséum national d'Histoire naturelle (Paris, France), and published osteological criteria for Iguana (Bochaton et al. 2016c), Diploglossus (Bochaton et al. 2016b), and Pholidoscelis (Bochaton et al. 2019a). The bird bones were identified using the osteological collections housed at the Musée archéologique Edgar Clerc (Le Moule, France); the Paleobiology and Birds Collections of the National Museum of Natural History, Smithsonian Institution (Washington, USA); and the Florida Museum of Natural History, University of Florida (Gainesville, USA).

The quantification units for faunal remains are the Number of Identified Skeletal Parts (NISP) and the Minimum Number of Individual or MNI (Lyman 1994). The MNI used here is a frequency MNI as defined by Poplin (1976). This was, when possible, preferentially calculated using skull bones for fish but is otherwise calculated on the most abundant anatomical element in a given assemblage. We also use the Percentage of Representation (PR) first used by Brain (1969) and formalized by Dodson and Wexlar (1979) to provide an account of the completeness of archaeological individuals. The analysis of fish trophic levels is based on the work of Wing and Wing (2001) and Blick (2007). The trophic level of each taxon was defined based on the data from Fishbase (Froese and Pauly 2018) from 1 (primary consumer) to 5 (carnivore) (Reitz and Wing 2008). The classification of Caribbean marine ecosystems follows Newsom and Wing (2004). Size reconstruction of Parrotfish (Sparisoma sp.) was based on the measurements and equations defined by Grouard (Grouard et al. 2019) for the lateral (measurement 3) and central (measurement 1) pharyngeal bones. Size reconstruction of iguanas was based on measurements taken from a broad range of skeletal elements following the work of Bochaton (2016).

All statistical analyses and tests were performed with the software R (R Core Team 2017) and the base package stats v3.4.3.

\section{Paleoproteomic analysis}

Several fragments of large mammals were identified, mostly from level 1. Zooarchaeology by Mass Spectrometry (ZooMS) analysis of five of these bones was carried out in order to obtain taxonomic information to test for the presence of introduced European animal species in the assemblage (see detailed methodology in Sup. Text. 2).

\section{Results}

\section{$\underline{\text { Ceramic analysis }}$}

All the recovered remains were included in our technological and morpho-stylistic analyses, the majority of which were collected in the levels 1 and 2 of B0B2 (Sup. Tab. 4 and 5). All fragment types were inventoried by 
stratigraphic features (Sup. Tab. 6) and the profiles of 567 vessels were reconstructed (Sup. Tab. 7). The morphological data was then cross-referenced with data on decoration (Sup. Tab. 8). It was not possible to clearly characterize each of the layers from a cultural point of view but the overall stratigraphic distribution of the various ceramic components remains chronologically coherent. The occupation of the site of Roseau seems to be primarily associated with the Troumassoid series but also presents a more discrete Cayo component that are described below. A technological analysis was also performed (see Sup. Text 3).

The Troumassoid component: The greater part of the ceramic series of Roseau is associated with the Troumassoid series. This series covers the Late and Final Ceramic periods (Bérard 2019) and presents in the Windward Islands as two sub-series: The Troumassan Troumassoid in the Late Ceramic period and the Suazan Troumassoid in the Final Ceramic period. Features of both sub-series are clearly represented in the Roseau collection, including elements that are present across both entities (tripod griddles, painted Calivigny style motifs, lugs, clay spindle whorls (Fig. 3-a), etc.). A number of features (shapes and decorations) from level 3 and to some extent from level 2 clearly indicate the presence of a Troumassan Troumassoid component in Roseau. This is particularly true of a set of thin walled carinated vessels, cazuelas, various jars, and the fragment of a boat shaped vase (Fig. 3-a-a). Other elements (red slip decorations and large oval ribs) from the same levels are indicative of a more northern influence (Marmoran Troumassoid). This is not surprising as the Guadeloupe islands are considered to be the geographical boundary between the Troumassan and Marmoran Troumassoid sub-series (Rouse and Faber Morse 1999). The higher part of the stratigraphy (level 2 and level 1) is clearly linked to the Suazan sub-series. These layers include a significant presence of simple forms with thick walls and scratched surfaces, finger indented rims or anthropomorphic adornos (Fig. 3-b). Northern influences (Chicoid) could also be distinguished in these upper levels.

The Cayo component: In addition to the Troumassoid component that constitutes the main part of the assemblage, different elements primarily from levels 0 and 1 are indicative of a Cayo Component. The Cayo complex is now known to be distinctly associated with the first colonial Contact period in the Lesser Antilles (1500-1620) and is related to a continental influence (Koriabo) that is visible in the style of ceramic production. This ceramic style has been identified in deposits demonstrating the importance of the contacts and influences involving Island Carib/Kalinago people of the Lesser Antilles, other Amerindian populations, and Europeans during this pre-colonial phase. In these assemblages a Suazan Troumassoid cultural background is associated with elements of European, continental (Koriabo) and northern (Chicoid and Meillacoid) origin (Hofman et al. 2019, 2020). The Cayo ceramic of Roseau is characterized by the use of sandy and sometimes vegetable tempering agents and a care brought to the surface treatments. In that respect, it clearly differs from the Suazan Troumassoid production which presents a coarser aspect. In terms of vessel shapes, the Roseau collection includes containers that can be compared to the type-shapes 2, 3, 5 and probably also to shape 7 of Boomert topology (Boomert 1986). We found in the series a whole set of Cayo characteristic decorations (Boomert 1986; Hofman et al. 2019, 2020): vertical appliqué nubbin, adornos on vertical strap handles, head lugs on vessel body and punctuated designs.

\section{$\underline{\text { Revaluation of the stratigraphy and dating of the site }}$}

The drawing of the stratigraphic section made by G. Richard (2003) (Fig. 2-a) shows signs of possible disturbance, such as the presence of gravel at the base of the ravine that suggests the passage of a watercourse, the imbrication of numerous concave-base lenses indicative of erosion, and a marked segregation of archaeological material types similar to the redistribution of material by water flow (Reading 2009). Such features could be indicators of several stratigraphic perturbations that might have impacted the chronological distinction between the strata of the assemblage (Lenoble 2005). The corrections for reservoir effect of the 14C dates previously obtained on marine material shows how uncertain they are and highlight they poor interest to characterize the chronology of the accumulation (Fig. 2-d). In contract, radiocarbon dates obtained on rodent teeth are generally coherent with the stratigraphy, but a few anomalies suggest there may have been some mixing of material between the strata (Fig. 2-b; Sup. Tab. 1). Obtained dates are in accordance with two main periods of occupation periods between the eleventh and fourteenth centuries $\mathrm{AD}$, but a single date also attests to the possible occurrence of rare elements dated to the Contact period in the stratigraphy. The interpretation of the recognized archaeological layers is as follows: 1300 to about $\mathrm{AD} 1400$ for level 1; $1200-1300 \mathrm{AD}$ for level 2; 
and 1000 to AD 1150 for level 3. Previous studies of the site identified level 1 in Roseau as Contact period, level 2 as Suazan Troumassoid, and level 3 as Troumassan Troumassoid (Richard, 2003). The presented ceramic analysis, combined with the newly obtained $14 \mathrm{C}$ dates, clearly identify most of the site occupation as associated with the Late and Final Ceramic periods. Levels 2 and 3 are dated to the Late Ceramic period with Troumassan and Marmoran cultural components. A second Suazan Troumassoid component that is marginally present in level 2, and accounts for the majority of the ceramic material in level 1, is identified as the Final Ceramic period. Finally, the site was also occupied at the beginning of the Contact period, as is clearly shown by a few minor features in level 1, and more distinctly from pieces characteristic of the Cayo complex recovered from the surface levels (levels 1 and 0). The presence of the Cayo component in level 1 is difficult to quantify, however most of the $\mathrm{C} 14$ dates conducted in this level (six out of seven) point to a pre-contact period corresponding to the Late Ceramic period (Suazan Troumassoid cultural current) and only a single date points to the Contact period. As the recovered archaeological elements from level 1 correspond mostly to a Suazan Troumassoid occupation, the majority of the layer cannot be attributed to the Contact period. Traces of contamination are present across the layers, with Cayo ceramic elements occurring in level 2, and a green iguana (Iguana iguana) bone in level 1, a species introduced during the modern era to Guadeloupe. It is possible that a Contact period occupation occurred on the site, creating a substantially altered surface layer that is impossible to delineate. In any case, the site of Roseau documents more than half a millennium of indigenous occupation of the island of Basse-Terre with important continental and northern cultural influences, which can be divided in two periods, the Late Ceramic (level 2 and 3), and the Final Ceramic (level 1).

\section{$\underline{\text { Zooarchaeological analysis }}$}

The zooarchaeological assemblage from Roseau beach is composed of 8,591 bone remains. The complete quantification of the full assemblage is presented in Sup. Tab. 9. Among these remains, 6,533 (76\%) were of known stratigraphic origin. The remaining bones are of uncertain origin either because they were collected on the surface or because the record of their stratigraphic origin has been lost since the excavation. The surface of the bones in every layer were often highly damaged with desquamations and presence of roots imprints which made the observation of possible cut marks more difficult. The fragmentation of the remains was not recorded with precision but appeared homogenous in all layers and allowed for an overall good percentage $(60 \%)$ of the bone to be taxonomically identified.

\section{Fish remains}

Fish are the most numerous taxonomic group in the assemblage, represented by 3,859 bone remains of which 1,128 have been identified at least to family, and correspond to an NMI of 222 individuals. A total of 47 taxa (to genus or species) distributed across 32 families have been identified. The families with the most abundant representation are Scaridae (22.1\% of the MNI) and Scombridae (12.6\% of the MNI) (Sup. Tab. 9). Nine other families represent between 7.2 and $3.6 \%$ of the MNI, in order of decreasing abundance: Labridae, Serranidae, Lutjanidae, Carangidae, Belonidae, Haemulidae, Acanthuridae, Centropomidae, and Sphyraenidae (Sup. Tab. 9). The remaining 21 families each represent less than $2 \%$ of the total MNI (Sup. Tab. 9). The distribution of anatomical elements indicates that whole fish were transported to the site: all anatomical elements are represented with a good representation of vertebrae (44.75\% of the NISP), of the skull and jaw bones (19.8\% of the NISP), and of the spines (17.85\% of the NISP).

There is a chronological evolution in the composition of the assemblage NISP; the proportion of coral reef, shallow inshore water and pelagic fish species varies between level 1 and levels 2-3 (khi² test; p.val <0.01) with a weaker representation of coral reef fish in level 1 (Fig.5-a). Levels 2 and 3 do not significantly differ in NISP composition ( $\mathrm{khi}^{2}$ test; p.val >0.01). This chronological trend is not apparent when comparing the MNI of the different levels. This could be due to either the high diversity of rare species represented in the different levels of the assemblage, or the NMI quantification method overestimating the importance of coral reef fish (Lyman 1994). The portion of the assemblage that was manually collected (635 remains) probably also contributed to an overrepresentation of the larger taxa, resulting in a skewed archaeo-ichthyological assemblage profile (Casteel 1976; Clason and Prummel 1977). In this case, this probably led to an overrepresentation, especially in level 1, of the common snook (Centropomus undecimalis), a fish that can reach more than $1.4 \mathrm{~m}$ in length (Froese and 
Pauly 2018). The remains collected using sieving do seem to confirm however that level 1 is characterized by a better representation of pelagic fishes, especially Scombridae (tuna) (Fig.5-b).

The mean trophic level represented by the fish remains is stable across the three layers of the site (between 3.8 and 3.7). Sparisoma sp. was the only genus for which size reconstruction of a significant number of specimens was possible. The 38 individual size reconstructions ( 2 for layer 1 and 36 for layers 2 and 3 ) indicate that most of the specimens present intermediate sizes between 200 and $360 \mathrm{~mm}$ in length (Fig. 5-c). The distribution of these sizes does not follow a normal distribution (Shapiro-Wilk test; p.val<0.01) and no size differences can be observed between the three recognized stratigraphic levels.

\section{Reptile remains}

A total of 623 reptile bones have been identified in the complete Roseau assemblage, 391 of known stratigraphic origin information, representing at least 41 individuals (Sup. Tab. 9). Squamates (snakes and lizards) are the most abundant with 473 remains representing at least 43 individuals; in level 1 in particular, squamate bones represent $26 \%$ of the total remains. The assemblage is dominated by iguana bones, accompanied by a few remains of two species of Alsophis snake, one of which (Alsophis sp. 2) is now extinct in Guadeloupe (Bochaton et al. 2019b). The other rare squamates are two lizard taxa that are also now extinct in Guadeloupe: an anguid lizard of the genus Diploglossus that has also been identified at other sites on the island (Bochaton et al. 2016b), and a unidentified species of ground lizard (Pholidoscelis sp.) that is frequently represented in Guadeloupian Amerindian assemblages (Bochaton et al. 2019a). The majority of the squamate remains represent at least 33 individual iguana, represented by 444 elements. Previously published osteological criteria (Bochaton et al., 2016b) enable 58 of the skeletal elements to be identified as lesser Antillean iguana (Iguana delicatissima). The only exception is a remain found in level 1, identified as green iguana (Iguana iguana), a species introduced to Guadeloupe during the modern period (Breuil 2002; Bochaton et al. 2016a).

Only four cut marks and no burning traces were observed on the iguana material, $7.4 \%$ of the bones were unbroken, and the PR was low (14\%). These observations do not differs markedly from those of other deposits, as iguana bones rarely present surface alterations of anthropic origins (Bochaton et al. 2016a). It was possible to obtain a size estimation of complete individuals from 78 of the bone remains using published equations (Bochaton 2016).

The distribution of the calculated sizes follows a normal distribution (Shapiro-Wilk test; p. val $>0.01$ ) and indicates that all the individuals from the site are of an adult size, with most specimens falling between 350 and $450 \mathrm{~mm}$ for snout-vent length (Fig. 5-d). The size of these iguanas is similar to the size observed in the other preColumbian sites of Basse-Terre (Bochaton et al. 2016a) and combined with the taphonomic features it may be inferred that these animal were selected, hunted and transported intentionally to the site in order to be consumed. A worked iguana long bone diaphysis with striations was also uncovered, which may have been used as a bead (Fig. 6-d). The stratigraphic origin of this object is however lost. To our knowledge this worked bone is unlike any other objects previously uncovered in Lesser Antillean archaeological deposits, and it is also only the third occurrence of a squamate bone worked (Bochaton 2020) and the first for a lizard.

There were 150 turtle remains uncovered corresponding to at least 5 individuals (Sup. Tab. 9), identified as marine turtles in the family Cheloniidae. The high fragmentation and poor preservation stage of the material preclude any more precise specific or generic identification on the basis of morphology. The majority (113 elements) of the remains are fragments of carapace. Only four elements display cut-marks and one has been burnt, but in general the poor preservation of the bones surfaces prevent any other surface observations.

\section{Bird remains}

The full bone assemblage contains 94 bird bones, 53 of which have been identified at least to the level of order (Sup. Tab. 9). The taxonomic diversity is very high, the relatively small sample of identified bones representing at least 15 species and 20 individuals. Because of the scarcity of bird remains and the lack of stratigraphic information for the most part, it is not possible to assess the differences in bird diversity between the layers. Procellariiforms are the taxa with the greatest representation (34\% of identified bird NISP) followed by 
Passeriformes (23\%) and Columbiformes (19\%). The remaining 24\% represent five different orders: Anseriformes, Pelecaniformes, Gruiformes, Strigiformes and Psittaciformes. The Black-capped Petrel (Pterodroma hasitata) is among one of the more remarkable taxa uncovered. This species went extinct during historical times in Guadeloupe and remains have only previously been recovered at the Amerindian site of Rivière du Baillif (Grouard 2001a). Other notable species include the Forest Thrush (Turdus lherminieri) in layer 3, indicating the proximity of a tropical moist forest (Parashuram et al. 2015); a giant owl similar to the fossil species of the Greater Antilles and to the Pleistocene remains of Tyto sp. found in Barbuda (Steadman and Hilgartner 1999; Suárez and Olson 2015) suggesting the occurrence of large owls in pre-contact Amerindian Guadeloupe; and an Amazon parrot (Amazona sp.) not previously mentioned in the other archaeological sites of Basse-Terre. The past occurrence of Amazona in the Guadeloupe Islands is, however, mentioned in historical sources (Williams and Steadman 2001), and a few bone remains have been recovered from two Ceramic Age sites in Marie-Galante and in the La Désirade islands (Grouard 2001a; Olson and López 2008).

\section{Mammal remains}

The majority of the mammal remains in the site assemblage are small rodents. Among the 582 remains identified as rodents, 405 are of known stratigraphic origin and represent a minimum of 35 individuals. This material was recovered primarily from levels 2 and $3(93 \%)$ and is mostly comprised of the Barbuda and Guadeloupe oryzomyine rat (Antillomys rayi) (Fig. 6-b) and of agouti (Dasyprocta leporina) (Fig. 6-c). The former is the most abundant mammal in level 2 ( $\mathrm{n}=130,71 \%$ total level NISP), the latter most abundant in the level 1 ( $\mathrm{n}=131$, $67 \%)$.

The absence of juvenile bones, and the presence of traces of digestion combined with cut marks and traces of burning on a small portion of the remains $(n=32)$ of both species leaves little doubt of the anthropogenic nature of this bone accumulation. In addition to the remains of small mammals, eighteen remains of large mammals were identified exclusively from level 1. One of these is the distal part of a manatee rib (Fig. 6-a). This constitutes the first Pre-Columbian archaeological occurrence of a non-worked bone of this animal in Guadeloupe (Ramos Roca and Perez Iglesias 2015). The other large mammal remains are heavily fragmented and impossible to identify from morphological criteria. Five of the fragmented bones were selected for palaeoproteomic analysis (see below) and all the fragments were identified as human. It is therefore extrapolated that all the fragmented bone is of human origin; no markings of any sort were observed on this material and there is no available evidence regarding its origin and depositional history.

\section{Paleoproteomics analysis}

All five samples analysed were identified as hominid. The B marker in all samples is present at $\mathrm{m} / \mathrm{z} 1477$, which is highly diagnostic for humans, Neanderthals, and Denisovians, separating them from other primates (Brown et al. 2016). Given the archaeological context, the identification as human may be readily accepted and the hypothesis of the presence of domestic mammals in the stratigraphy of Roseau rejected.

\section{General zooarchaeological remarks}

The proportions of the vertebrate taxa (fish, mammals, reptiles, birds) differ significantly between each of the three levels at Roseau (pair wise chi $^{2}$ test; p.val <0.01). Across the layers there is a progressive increase in the proportion of terrestrial fauna, from $6 \%$ in level 3 to $12 \%$ in level 2, and $49 \%$ in level 1 . In addition to this transition there are two secondary chronological changes. The first is a shift from the exploitation of a native small mammal (Antillomys rayi) that represent $70 \%$ of the mammal remains in level 2 and 3, towards that of an introduced rodent (Dasyprocta leporina), representing 75\% of the small mammal remains in level 1 . There is also a shift from coral reef fishing toward more pelagic fishing. Our zooarchaeological analysis provides no evidence that this evolution is a reflection of taphonomic bias as the quality of the preservation and the fragmentation of the remains are homogeneous across the deposit and all types of taxa uncovered exhibit evidence of human exploitation. There is also no zooarchaeological evidence of an overexploitation of the marine environments that may have forced the Amerindian groups towards more terrestrial subsistence strategies. This is demonstrated by the absence of evolution of the mean trophic level and of the sizes of the 
fished fishes in the different layers. The shell assemblage may provide complementary information to the pattern observed in the vertebrate assemblage, but this study has not yet been conducted.

\section{DiscussionThe Roseau zooarchaeological assemblage in the regional context}

The bone assemblage in the lower levels of the site ( 2 and 3 ) is mostly composed of marine vertebrates, typical of most Lesser Antillean Amerindian assemblages. However the upper level (1), with its notable representation of reptiles and terrestrial vertebrates, bears a greater resemblance to the small number of Lesser Antillean Amerindian vertebrate assemblages that deviate from the general tendency towards a marine profile, and instead exhibit a composition containing less than $60 \%$ of marine vertebrates. Examples of other sites with a more vertebrate terrestrial profile include Hichmans on Nevis (Newsom and Wing 2004), Hope Estate on Saint-Martin (Newsom and Wing 2004), Trants on Montserrat (Reitz 1994), and Morel in Guadeloupe (Grouard 2001b, 2007).

The plentiful diversity of fish species in the zooarchaeological vertebrate assemblage of Roseau is similar to most Guadeloupian and Lesser Antillean assemblages (Grouard 2001a; Newsom and Wing 2004; de Waal 2006). The only unusual fish taxa uncovered are Bothidae and Scorpaenidae, which have not been found previously in the archaeological record of Guadeloupe. The abundant presence of Scaridae is common in zooarchaeological assemblages as coral reefs were intensively exploited by Lesser Antillean Amerindians (Grouard 2001a; Wing 2001a, b; Newsom and Wing 2004; de Waal 2006).

Bird remains found at Roseau have a similar profile to the other lesser Antillean Amerindian sites with a similar proportion of the principally represented orders (in decreasing order of importance): Procellariiformes, Passeriformes, Columbiformes, and water birds (Anatidae, Ardeidae, and Ralidae). However, with 15 taxa present in the assemblage, the Roseau bird series displays a remarkably high taxonomic diversity despite the limited size of the assemblage. In comparison, the number of avian taxa in Guadeloupian pre-Columbian assemblages ranges between 1 and 7 (Wing and Reitz 1982; Grouard 2001a; Olson and López 2008; Stouvenot et al. 2014). This could reflect both the variety of environments surrounding the site (mesophilic forest, xerophilic forests, and coastal habitats), and possibly the collaboration of a paleo-ornithologist in the study.

In respect to reptiles, Roseau does not present any notable differences in comparison to other assemblages from Guadeloupe in terms of the taxonomic diversity.

\section{Evolution of fishing techniques}

The size of Parrot fish (Sparisoma sp.) from the site indicates that medium sized specimens (between 160 and $279 \mathrm{~mm}$ in total length) of sub-adult proportions are the most represented. This could indicate the use of selective fishing techniques (fishnet, trap, hooks) in reef areas (Grouard 2001a). Fishing techniques vary markedly depending on the depth and morphology of the seabed (Bonniol 1980) so it is difficult to propose which specific methodologies may have been practiced by the people who occupied the site.

The possible increase of deep sea water fishing (Scombridae) may reflect a technological evolution with an increasing use of boats in fishing activities. Ethnographic comparisons may provide examples of the methods that could have been used. In the eighteenth century the most commonly used technique to fish pelagic fish was trawling with three fishermen in the boat, two maintaining the boat against the winds and currents and the third managing the lines attached to wood or bone hooks (Guillou and Lagin 1997). This technique enables a catch of a maximum of $500 \mathrm{~kg}$ of fish for a single boat and is still the method the most commonly used in the present day (Reynal and Taquet 2015). In general, notwithstanding whichever techniques may have been used, deep sea fishing methods require more human and material investment that the fish methods applied in areas of coral reef (Grouard 2001a; Newsom and Wing 2004).

\section{Evolution of vertebrate exploitation strategies}

The faunal vertebrate assemblages differ notably between level 1 dating to the Contact/Final Ceramic period and levels 2 and 3 dating to the Late Ceramic period. The vertebrate consumption shifts from a nearly exclusive exploitation of coral reef marine resources to a mixed exploitation of terrestrial resources and a greater frequency 
of pelagic fishing. This shift contradicts the general regional trends of the increasing role of coral reef fish in the subsistence economy during the Ceramic Age (Grouard et al. 2019) and instead aligns with the development of more specialized economies having a higher focus on pelagic fishing in volcanic islands (Grouard 2003). Roseau beach is situated near to a river mouth and at the interface between the reef formation of the Grand Cul de Sac marin and the deep sea of the Saintes channel. Both coral reef and pelagic fishing would therefore have been possible, as tuna have been documented following the streams in the Saintes channels between January and June (Bonniol 1980). In addition, two other Guadeloupian sites that exhibit a notable proportion of pelagic fish in their zooarchaeological assemblages (Grande Anse and Riviére de Baillif) are also situated in the southern area of the Basse-Terre Island (Grouard 2001a).

Data from terrestrial fauna indicates that Lesser Antillean Rice rats were initially hunted and then replaced by the hunting of agouti. Agoutis were already present in Guadeloupe at the beginning of the Saladoid period (Grouard 2001a) and were probably available for predation in Guadeloupe during the first occupation phase of Roseau. The increase of their proportion in the assemblage could be due to a release of hunting pressure. Indeed, cases where the environment is not over-exploited; foragers tend to restrict their hunting spectrum around the most energy-efficient species (MacArthur and Pianka 1966) and in neotropical environments, agoutis (and iguanas) are high-ranking resources (Hames and Vickers 1982; Keegan 1989; Alvard 1993) certainly offering a higher energy return than that provided by the Rice rats. The management of Agoutis by human populations is an alternative hypothesis and an isotopic study similar to the work recently conducted on archaeological Bahamas hutia (LeFebvre et al. 2019) would be needed to investigate this question. In parallel with this shift in rodent exploitation, iguanas also began to be hunted, a phenomenon corroborated by $17^{\text {th }}$ and $18^{\text {th }}$ centuries historical sources (Du Tertre 1654; Monpilliers 1654; Grunberg 2013), and these lizards are even more numerous than rodents in level 1. This observation could be related to the similar pattern observed on agoutis but is otherwise is difficult to comment further as there are no clear patterns of squamate exploitation in Amerindian deposits, and such behavior may primarily reflect socio-cultural tendencies that are impossible to document.

A Cayo component in the ceramic assemblage marking the arrival of exogenous cultural influences in the Lesser Antilles is present in the layer 1 in which the changes in vertebrate exploitation were observed. However, this component is probably too minor to fully explain the changes. Thus, the most likely hypothesis to explain the observed vertebrate exploitation shift is unlikely related to any strong cultural evolution/change/replacement and probably to more subtle causes, some of which are discussed below.

There are very few examples in the Lesser Antilles of an intra-site chronological vertebrate exploitation transition. A similar but less spectacular transition was observed at the site of Keldey's Ridge in Saba (Wing 2001a). In the Troumassoid site of Sabazan (Grenadines) (Giovas 2016b) the inverse was suggested with a putative progressive decrease in terrestrial vertebrates over time but the bone material was not abundant enough to draw clear conclusions. These two examples alone show that either that there is no simple regional trend as has been previously hypothesized (Jones 1985; Wing 1989) or that global patterns are still impossible to determine due to the lack of data describing the most recent Amerindian periods in the Caribbean. In any case, the Roseau vertebrate assemblage confirms that terrestrially oriented diets are not specific to the earliest periods and can occur in the Final Ceramic, further confirmed by isotopic studies (Stokes 1998; Laffoon et al. 2016). Explaining subsistence behavior modification is complex as it does not seem to strictly adhere to either chronological or regional trends. As is demonstrated in this study, the shift at Roseau cannot be explained by an erosion of the coral reef and it is likely that this type of transition follows site-specific logic and emerges independently from chronology and broader cultural currents. Several hypotheses could nevertheless be formulated to explain the chronological changes observed at Roseau. First, the change could reflect a seasonal occupation as has been clearly demonstrated for Plum piece (Hofman and Hoogland 2003) and hypothesized for several other Amerindian sites (e. g. Antczak and Antczak, 2005; Serrand, 2007). However, this hypothesis is not supported by the isotopic data collected on Rice rats (Goedert et al. 2020) although the question of seasonal exploitation of fish remains open. Second, the practice of garden hunting (Linares 1976) could explain the abundance of agouti in the later phase of Roseau. It would need to be accompanied by other hunting strategies as garden hunting alone could not account for the exploitation of other taxa including Procellariiforms birds. Third, a better supported hypothesis would be that of a release of the hunting pressure on terrestrial fauna possibly 
compatible with discontinuous occupation of the site which led to a better representation of large size/high ranking animals in the more recent layers (Hames and Vickers 1982; Grouard 2001b; Wing 2001b). This could also be in accordance with the better representation of large offshore fishes in the same layer a pattern similar to the one suggested by the isotopic data of the Lavoutte Amerindian site (Laffoon et al. 2016). Finally, a cultural explanation should not be disregarded. For example, examples of Lesser Antillean Amerindian cultural food choices have been well documented historically by European chroniclers in the form of food taboo. Several authors testified that seventeenth century Amerindians refused to consume manatee as it was considered too fatty and was supposed to bring back diseases (Grunberg 2013). The native Lesser Antillean Amerindians also refuse to hunt Boa snakes that were reputed to avenge themselves on the grandchildren of the hunters. Other snakes species, as well as eels believed to be their sisters, were also not killed or consumed (Grunberg 2013). These testimonies find an echo in the archaeological record as the bones of the above mentioned taxa lack any trace of consumption, and are either very rarely found or found only as manufactured artifacts in Amerindian deposits (Ramos Roca and Perez Iglesias 2015; Bochaton et al. 2019b; Bochaton 2020).

\section{Conclusion}

The new study of the Roseau material underlines the complexity and variability of Ceramic Amerindian subsistence behaviors. The site suffers from the same limitations as many other regional excavations in terms of the limited portion of the site available for excavation and the low quality chronological and spatial characterization as a result of both biostratigraphic perturbation and poor preservation. The invertebrate assemblage of the site also remains unstudied and could provide valuable complements to our observations. However, despite these limitations, the zooarchaeological vertebrate material provides evidence for a previously unobserved exploitation strategy shift from predominantly marine resources with an emphasis on coral reef fish to terrestrial resources supplemented by pelagic fish. The rational for this change in subsistence is difficult to interpret considering how little is known of the chronology and cultural traits of the Ceramic Age Amerindians of the Lesser Antilles. Despite its rich archaeological record and the numerous hypotheses that have driven zooarchaeological research in the region, no predominant pattern in subsistence strategy has emerged. Different strategies exist within the same period as a result of a complex intersection of cultural, ecological, and environmental contexts providing a picture of a highly diverse and adaptive set of regional substance strategies that were present in the Lesser Antilles during the Ceramic Age. The quality of zooarchaeological data present from often limited excavations allows for observations of changing subsistence strategies. Increased excavations and improved chronologies at sites across the region will allow for a better understanding of the nature of these subsistence changes and the further investigation of the environmental, ecological, or cultural drivers for these behavior changes.

\section{References}

Allaire L (1977) Later prehistory in Martinique and the Island Caribs: problems in ethnic identification. Ph.D. dissertation, Yale University

Allen JP, Crock JG, Carder N (2011) Zooarchaeological analysis of fishing at the Rendezvous Bay site, Anguilla: an investigation into possible overexploitation of marine fishes. In: Murphy R, Rebovitch S (eds) Proceedings of the 24th International Congress for Caribbean Archaeology. St. John, Antigua, pp $138-146$

Alvard MS (1993) Testing the "ecologically noble savage" hypothesis: Interspecific prey choice by Piro hunters of Amazonian Peru. Hum Ecol 21:355-387. https://doi.org/10.1007/BF00891140

Antczak A, Antczak MM (2005) Pre-Hispanic Fishery of the Queen Conch, Strombus gigas, on the Islands off the Coast of Venezuela. In: Miloslavich P, Klein E (eds) Caribbean Marine Biodiversity: the Known and Unknown. DEStech Publications, Lancaster, pp 213-243

Bérard B (2019) About Boxes and Labels: A Periodization of the Amerindian Occupation of the West Indies. J Caribb Archaeol 19:51-67 
Bérard B (2004) Les premières occupations agricoles de l'arc antillais, migration et insularité. Le cas de l'occupation saladoïde ancienne de la Martinique. BAR Int Ser 1299:214

Blick JP (2007) Pre-Columbian impact on terrestrial, intertidal, and marine resources, San Salvador, Bahamas (A.D. 950-1500). J Nat Conserv 15:174-183. https://doi.org/10.1016/j.jnc.2007.04.004

Bochaton C (2016) Describing archaeological Iguana Laurenti, 1768 (Squamata: Iguanidae) populations: size and skeletal maturity. Int J Osteoarchaeol 26:716-724. https://doi.org/10.1002/oa.2463

Bochaton C (2020) First records of modified snake bones in the Pre-Columbian archaeological record of the Lesser Antilles: Cultural and paleoecological implications. J Isl Coast Archaeol. https://doi.org/10.1080/15564894.2020.1749195

Bochaton C, Bailon S, Ineich I, et al (2016a) From a thriving past to an uncertain future: Zooarchaeological evidence of two millennia of human impact on a large emblematic lizard (Iguana delicatissima) on the Guadeloupe Islands (French West Indies). Quat Sci Rev 150:172-183. https://doi.org/10.1016/j.quascirev.2016.08.017

Bochaton C, Boistel R, Casagrande F, et al (2016b) A fossil Diploglossus (Squamata, Anguidae) lizard from Basse-Terre and Grande-Terre islands (Guadeloupe, French West-Indies). Sci Rep 28475:1-12

Bochaton C, Boistel R, Grouard S, et al (2019a) Evolution, diversity and interactions with past human populations of recently extinct Pholidoscelis lizards (Squamata: Teiidae) from the Guadeloupe Islands (French West-Indies). Hist Biol 31:140-156. https://doi.org/10.1080/08912963.2017.1343824

Bochaton C, Boistel R, Grouard S, et al (2019b) Fossil dipsadid snakes from the Guadeloupe Islands (French West-Indies) and their interactions with past human populations. Geodiversitas 41:501-523

Bochaton C, Grouard S, Breuil M, et al (2016c) Osteological differentiation of the Iguana Laurenti, 1768 (Squamata: Iguanidae) Species: Iguana iguana (Linnaeus, 1758) and Iguana delicatissima Laurenti, 1768, with some comments on their hybrids. J Herpetol 50:295-305. https://doi.org/10.1670/14-170

Bonniol J-L (1980) Terre-de-Haut des Saintes. Contraintes insulaires et particularisme ethnique dans la Caraïbe, Les Editions Caribéennes. Paris, France

Bonnissent D (2008) Archéologie précolombienne de l'île de Saint-Martin, Petites Antilles (3300 BP - 1600 AD). Thèse de doctorat, Université Aix-Marseille

Bonnissent D (2005) La céramique du site postsaladoïde de Baie aux Prunes (Plum Bay) : les implications chronologiques et géographiques (Saint-Martin, Petites Antilles). In: Proceedings of the XXth International Congress for Caribbean Archaeology. Museo del Hombre Dominicano, Santo Domingo, pp 41-48

Boomert A (1986) The Cayo complex of St. Vincent: ethnohistorical and archaeological aspects of the Island Carib problem. Antropologica 66:3-68

Boomert A (2011) Searching for Cayo in Dominica. In: Rebovitch S (ed) The Proceedings of the XXIII Congress of the International Association for Caribbean Archaeology. English Harbour, Dockyard Museum, Antigua, pp 655-678

Brain CK (1969) The contribution of Namib Desert Hottentots to an understanding of australopithecine bone accumulations. Sci Pap Namib Desert Res Stn 1969:13-22

Breuil M (2002) Histoire naturelle des amphibiens et reptiles terrestres de l'archipel guadeloupéen: Guadeloupe, Saint-Martin, Saint-Barthélémy. Publications Scientifiques du Muséum National d'Histoire Naturelle, France

Brown S, Higham T, Slon V, et al (2016) Identification of a new hominin bone from Denisova Cave, Siberia using collagen fingerprinting and mitochondrial DNA analysis. Sci Rep 6:1-8. https://doi.org/10.1038/srep23559 
Carbone VA (1980) The paleoecology of the Caribbean area. Fla Anthropol 33:99-119

Carder N, Crock JG (2012) A pre-Columbian fisheries baseline from the Caribbean. J Archaeol Sci 39:31153124. https://doi.org/10.1016/j.jas.2012.04.038

Carder N, Reitz EJ, Crock JG (2007) Fish communities and populations during the post-Saladoid period (AD 600/800-1500), Anguilla, Lesser Antilles. J Archaeol Sci 34:588-599

Carlson LA, Steadman DW (2009) Examining Temporal Differences in Faunal Exploitation at Two Ceramic Age Sites in Puerto Rico. J Isl Coast Archaeol 4:207-222. https://doi.org/10.1080/15564890903142842

Casteel RW (1976) Comparison of column and whole unit samples for recovering fish remains. World Archaeol 8:192-196. https://doi.org/10.1080/00438243.1976.9979663

Clason AT, Prummel W (1977) Collecting, sieving and archaeozoological research. J Archaeol Sci 4:171-175. https://doi.org/10.1016/0305-4403(77)90064-4

Clerc E (1964) Le peuplement précolombien des Antilles et ses vestiges en Guadeloupe. Bull Société Hist Guadeloupe 2:18-32

de Waal MS (2006) Pre-Columbian social organization and interaction interpreted through the study of settlement patterns: An archaeological case-study of the pointe des Châteaux, La Désirade and les Îles de la Petite-Terre micro-region, Guadeloupe, F.W.I. PHD thesis, Leiden University

deFrance SD (1990) Zooarchaeological investigations of an early ceramic age frontier community in the Caribbean: The Maisabel site, Puerto Rico. Antropologica 73-74:3-180

Delpuech A (2001) Guadeloupe amérindienne, Editions du Patrimoine. Paris, France

DiNapoli RJ, Fitzpatrick SM, Napolitano MF, et al (2021) Marine reservoir corrections for the Caribbean demonstrate high intra- and inter-island variability in local reservoir offsets. Quat Geochronol 61:101126. https://doi.org/10.1016/j.quageo.2020.101126

Dodson P, Wexlar D (1979) Taphonomic Investigations of Owl Pellets. Paleobiology 5:275-284

Du Tertre J-B (R. P) (1654) Histoire générale des isles de S. Christophe, de la Guadeloupe, de la Martinique, et autres dans l'Amérique. A Paris : Chez Jacques Langlois et Emmanuel Langlois, Paris

Froese R, Pauly D (2018) Fishbase. http://www.fishbase.org

Giovas CM (2016a) Though She Be But Little: Resource Resilience, Amerindian Foraging, and Long-Term Adaptive Strategies in the Grenadines, West Indies. J Isl Coast Archaeol 11:238-263. https://doi.org/10.1080/15564894.2016.1193572

Giovas CM (2016b) Pre-Columbian Amerindian Lifeways at the Sabazan Site, Carriacou, West Indies. J Isl Coast Archaeol 0:1-30. https://doi.org/10.1080/15564894.2016.1229702

Giovas CM, Fitzpatrick SM (2014) Prehistoric migration in the Caribbean: past perspectives, new models and the ideal free distribution of West Indian colonization. World Archaeol 46:569-589. https://doi.org/10.1080/00438243.2014.933123

Goedert J, Cochard D, Lorvelec O, et al (2020) Isotopic ecology and regional extirpation chronology of the extinct Lesser Antillean rat Antillomys rayi. Quarternary Sci Rev 245:106509

Goodwin RC (1979) The prehistoric cultural ecology of St. Kitts, West Indies: A case study in island archaeology. PhD thesis, Arizona State University

Grouard S (2007) Modes de vie des Précolombiens des Antilles françaises. In: Rostain S, Vidal N (eds) Archéologie des départements français d'Amérique, Editions de la Maison des Sciences de l'Homme. pp 91-101 
Grouard S (2001a) Subsistance, systèmes techniques et gestion territoriale en milieu insulaire antillais précolombien - Exploitation des Vertébrés et des Crustacés aux époques Saladoïdes et Troumassoïdes de Guadeloupe (400 av. J.-C. à 1500 ap. J.-C.). PHD thesis, Université Paris X

Grouard S (2001b) Faunal Remains Associated with Late Saladoïd and Post-Saladoïd Occupations at Anse à la Gourde, Guadeloupe, West Indies: Preliminary Results. Archaeofauna 10:71-98

Grouard S (2003) Subsistance et mode de vie des premiers habitants de Guadeloupe (500 av. - 1500 ap. J.-C.). Préhistoire Anthropol Méditerranéennes 10-11:191-214

Grouard S (2004) Variation des stratégies de subsistance des Précolombiens à Hope Estate, Saint-Martin (Petites Antilles), d'après l'analyse des restes des petits vertébrés. In: Petits animaux et sociétés humaines: du complément alimentaire aux ressources utilitaires. Éditions APDCA, Antibes, France, pp 451-467

Grouard S, Perdikaris S, Rodrigues NEE, Quitmyer IR (2019) Size estimation of pre-Columbian Caribbean fish. Int J Osteoarchaeol 29:452-468. https://doi.org/10.1002/oa.2782

Grunberg B (2013) Textes anonymes. Anonyme de Carpentras, Anonyme de Grenade, Anonyme de St Christophe, Anonyme de St Vincent, Anonyme dit "Gentilhomme écossais". Edition critique. L'Harmattan, Paris

Guillou A, Lagin A (1997) Engins et techniques de pêche de la Martinique, Ifremer. Le Robert, Martinique

Hames RB, Vickers WT (1982) Optimal diet breadth theory as a model to explain variability in Amazonian hunting. Am Ethnol 9:358-378. https://doi.org/10.1525/ae.1982.9.2.02a00090

Hofman CL (1993) In search of the native population of pre-columbian Saba (A.D. 400-1450). Part one : Pottery styles and their interpretations. Ph.D. dissertation, Leiden University

Hofman CL, Borck L, Laffoon JE, et al (2020) Island networks: Transformations of inter-community social relationships in the Lesser Antilles at the advent of European colonialism. J Isl Coast Archaeol 0:1-27. https://doi.org/10.1080/15564894.2020.1748770

Hofman CL, Hoogland ML (1999) Archaeological investigations on St. Martin (Lesser Antilles): The sites of Norman Estate, Anse des Pères and Hope Estate with a contribution to the 'La Hueca problem.' Faculty of Archaeology, Leiden University, Leiden, Netherlands

Hofman CL, Hoogland ML (2003) Plum piece: evidence for archaic seasonal occupation on Saba, northern lesser Antilles around 3300 BP. J Caribb Archaeol 12-27

Hofman CL, Hoogland MLP, Arie Boomert, Martin JA (2019) Colonial Encounters in the Southern Lesser Antilles: Indigenous Resistance, Material Transformations, and Diversity in an Ever-Globalizing World. Mater Encount Indig Transform Early Colon Am 359-384. https://doi.org/10.1163/9789004273689_017

Hofman CL, Hoogland MLP, Delpuech A (1999) New perspectives on a Huecan Saladoid assemblage on Guadeloupe: the case of Morel I. In: Archaeological investigations on St. Martin (Lesser Antilles). The sites of Norman Estate, Anse des Pères and Hope Estate, with a contribution to the "la Hueca problem," Faculty of Archaeology, Leiden University. Leiden, Netherlands, pp 303-310

Honoré S (2013) Évaluation archéologique du site de l'Anse du Coq, Marie-Galante, Guadeloupe. DRAC de la Guadeloupe/Conseil Régional de la Guadeloupe, Guadeloupe

Jones AR (1985) Dietary Change and Human Population at Indian Creek, Antigua. Am Antiq 50:518-536. https://doi.org/10.2307/280319

Keegan WF (1989) Transition from a terrestrial to a maritime economy: A new view of the crab/shell dichotomy. In: Early Ceramic Population Lifeways and Adaptive Strategies in the Caribbean. British Archaeological Reports, Oxford, United Kingdom, pp 119-128 
Keegan WF, Hofman CL, Ramos RR (2013) The Oxford Handbook of Caribbean Archaeology. Oxford University Press, Oxford

Laffoon JE, Hoogland MLP, Davies GR, Hofman CL (2016) Human dietary assessment in the Pre-colonial Lesser Antilles: New stable isotope evidence from Lavoutte, Saint Lucia. J Archaeol Sci Rep 5:168180. https://doi.org/10.1016/j.jasrep.2015.11.020

Le Lay A (2013) Étude du mobilier céramique du site de l'arrière-plage de Roseau: Vers une caractérisation culturelle de l'occupation post-Saladoïde en Basse-Terre de Guadeloupe (1000-1500 apr. J.-C.). Master thesis, Université Paris 1

LeFebvre MJ, deFrance SD, Kamenov GD, et al (2019) The zooarchaeology and isotopic ecology of the Bahamian hutia (Geocapromys ingrahami): Evidence for pre-Columbian anthropogenic management. PLoS ONE 14:. https://doi.org/10.1371/journal.pone.0220284

LeFebvre MJ, Giovas CM (2009) The Zooarchaeology of Islands: Towards Synergy and Synthesis. J Isl Coast Archaeol 4:141-150. https://doi.org/10.1080/15564890903149532

Lenoble A (2005) Ruissellement et formation des sites préhistoriques : référentiel actualiste et exemples d'application au fossile, Oxford. Oxford, United Kingdom

Linares OF (1976) "Garden hunting” in the American tropics. Hum Ecol 4:331-349. https://doi.org/10.1007/BF01557917

Lyman RL (1994) Vertebrate taphonomy. Cambridge University Press, New York (USA)

MacArthur RH, Pianka ER (1966) On Optimal Use of a Patchy Environment. Am Nat 100:603-609. https://doi.org/10.1086/282454

McKusick M (1960) Distribution of Ceramic Styles in the Lesser Antilles, West Indies. PhD thesis, Yale University

Monpilliers SD (1654) Description des voyages et avantures du Sr de Monpilliers, faits en diverses parties du monde, avec le récit de ses premières campagnes, qu'il a fait és années $1634,35 \& 36$ pour le service du Roy. Paris

Münch P, Lebrun J-F, Cornée J-J, et al (2013) Pliocene to Pleistocene carbonate systems of the Guadeloupe archipelago, French Lesser Antilles: a land and sea study (the KaShallow project). Bull Société Géologique Fr 184:99-110

Napolitano MF, DiNapoli RJ, Stone JH, et al (2019) Reevaluating human colonization of the Caribbean using chronometric hygiene and Bayesian modeling. Sci Adv 5:eaar7806. https://doi.org/10.1126/sciadv.aar7806

Newsom LA, Wing ES (2004) On Land and Sea: Native American Uses of Biological Resources in the West Indies. University of Alabama Press, United States of America

Olson SL, López EJM (2008) New evidence of Ara autochthones from an archeological site in Puerto Rico: a valid species of West Indian macaw of unknown geographical origin (Aves: Psittacidae). Caribb J Sci $44: 215-222$

Parashuram D, Oppel S, Fenton C, et al (2015) The Forest Thrush Turdus lherminieri prefers mature mesic forest with dense canopy. Bird Conserv Int 25:503-513. https://doi.org/10.1017/S0959270914000495

Politis GG, Saunders NJ (2002) Archaeological Correlates of Ideological Activity: Food Taboos and Spiritanimals in an Amazonian Hunter-gatherer Society. In: Milner N, Miracle P (eds) Consuming passions and patterns of consumption, McDonald Institute for Archaeological Research. Cambridge, UK, pp $113-130$ 
Poplin F (1976) A propos du nombre de restes et du nombre d'individus dans les échantillons d'ossements. Cah Cent Rech Préhistoriques 5:61-75

R Core Team (2017) R: A language and environment for statistical computing. Version 3.4.3. R Foundation for Statistical Computing, Vienna, Austria. URL http://www.R-project.org/

Rainey FG (1940) Scientific Survey of Porto Rico and Virgin Islands, New York Academy of Sciences. New York (USA)

Ramos Roca E, Perez Iglesias L (2015) Zooarcheological Evidence on the Utilization of Aquatic Mammals in Northern South America and the Caribbean: A Contribution to Long-Term Biological Conservation. In: Muñoz S, Götz CM, Ramos Roca E (eds) Neotropical and Caribbean Aquatic Mammals, nova science publishers. New York, pp 73-106

Reading HG (2009) Sedimentary Environments: Processes, Facies and Stratigraphy. John Wiley \& Sons

Reimer PJ, Austin WEN, Bard E, et al (2020) The IntCal20 Northern Hemisphere Radiocarbon Age Calibration Curve (0-55 cal kBP). Radiocarbon 62:725-757. https://doi.org/10.1017/RDC.2020.41

Reitz EJ (1994) Archaeology of Trants, Montserrat. Part 2. Vertebrate Fauna. Ann Carnegie Mus 63:297-317

Reitz ES, Wing ES (2008) Zooarchaeology 2nd Edition. Cambridge Manuals in Archaeology

Reynal L, Taquet M (2015) Le redéploiement de la pêche antillaise vers les grands poissons pélagiques. In: Blanchet G, Gobert B, Guérédrat J-A (eds) La pêche aux Antilles. IRD Éditions, Marseille, pp 73-86

Richard G (1994) Premier indice d'une occupation précéramique en Guadeloupe continentale. J Société Américanistes 80:241-242. https://doi.org/10.3406/jsa.1994.2768

Richard G (2003) Le site archéologique de la plage de Roseau à Capesterre Belle Eau révélateur d'une occupation caraïbe insulaire en Guadeloupe. In: Maria CT, García Arévalo MA (eds) Actes du XXe congrès international d'archéologie de la caraïbe, Museo del Hombre Dominicano y Fundación García Arévalo. Dominican Republic, pp 15-22

Rouse IB, Faber Morse B (1999) Excavations at the Indian Creek Site, Antigua, West Indies Yale University Publications in Anthropology, Peabody Museum of natural History. New Haven, USA

Rousteau A, Portecop J, Rollet B (1994) Carte écologique de la Guadeloupe.

Serrand N (2007) Exploitation des invertébrés par les sociétés précolombiennes des Petites Antilles. Société Américanistes 93:7-47

Siegel PE, Jones JG, Pearsall DM, et al (2015) Paleoenvironmental evidence for first human colonization of the eastern Caribbean. Quat Sci Rev 129:275-295. https://doi.org/10.1016/j.quascirev.2015.10.014

Steadman DW, Hilgartner WB (1999) A new species of exctinct barn owl (Aves: Tyto) from Barbuda, Lesser Antilles. Smithson Contrib Paleobiology 89:75-83

Stokes A (1998) A biogeographic survey of prehistoric human diet in the West Indies using stable isotopes. PhD thesis, Department of Anthropology, University of Florida

Stouvenot C, Grouard S, Bailon S, et al (2014) L'abri sous roche Cadet 3 (Marie-Galante): un gisement à accumulations de faune et à vestiges archéologiques. In: Bérard B, Losier C (eds) Archéologie Caraïbe. Sidestone Press, Leiden, Netherlands, pp 77-102

Stuiver M, Reimer PJ, Reimer RW (2020) CALIB. Version 7.1URL http://calib.org, accessed 2020-4-12

Suárez W, Olson SL (2015) Systematics and distribution of the giant fossil barn owls of the West Indies (Aves: Strigiformes: Tytonidae). Zootaxa 4020:533. https://doi.org/10.11646/zootaxa.4020.3.7 
van den Bel M, Belarbi M, Casagrande F, et al (2018) Parking de Roseau: Sainte-Marie avant l'arrivée de Christophe Colomb. INRAP, Bègles, France

Williams M, Steadman D (2001) The Historic and Prehistoric Distribution of Parrots (Psittacidae) in the West Indies. In: Woods CA, Sergile FE (eds) Biogeography of the West Indies: Patterns and Perspectives, Second Edition. Boca Raton, Gainesville, USA, p 17589

Wing E, Scudder SJ (1980) Use of animals by the prehistoric inhabitants of St. Kitts. In: Lewenstein SM (ed). Arizona State University Annthropologucal Research Paper, pp 237-245

Wing ES (2001a) Native American use of animals in the Caribbean. In: Wood CA, Sergile FE (eds) Biogeography of the West Indies: patterns and perspectives, CRC Press. Boca Raton, pp 481-518

Wing ES (1989) Human exploitation of animal resources. In: Wood CA (ed) Biogeography of the West Indies: Past, Present, Future. Sandhill Crane Press, Gainesville, Florida, pp 137-152

Wing ES (2001b) The sustainability of resources used by Native Americans on four Caribbean islands. Int J Osteoarchaeol 11:112-126. https://doi.org/10.1002/oa.550

Wing ES, Reitz EJ (1982) Prehistoric fishing economies of the Caribbean. J New World Archaeol 5:13-32

Wing S, Wing E (2001) Prehistoric fisheries in the Caribbean. Coral Reefs 20:1-8. https://doi.org/10.1007/s003380100142

\section{Figures Captions}


a

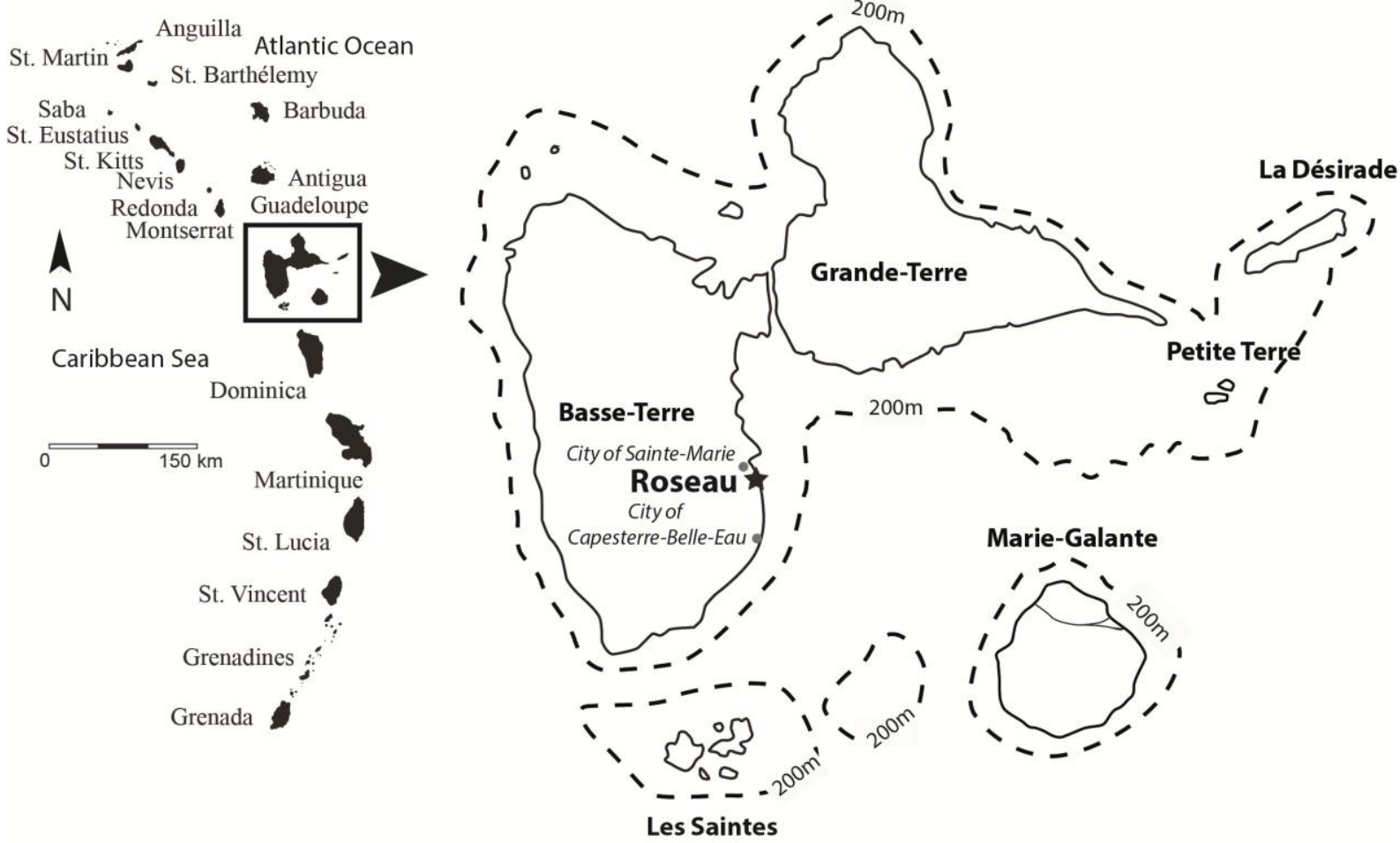

b

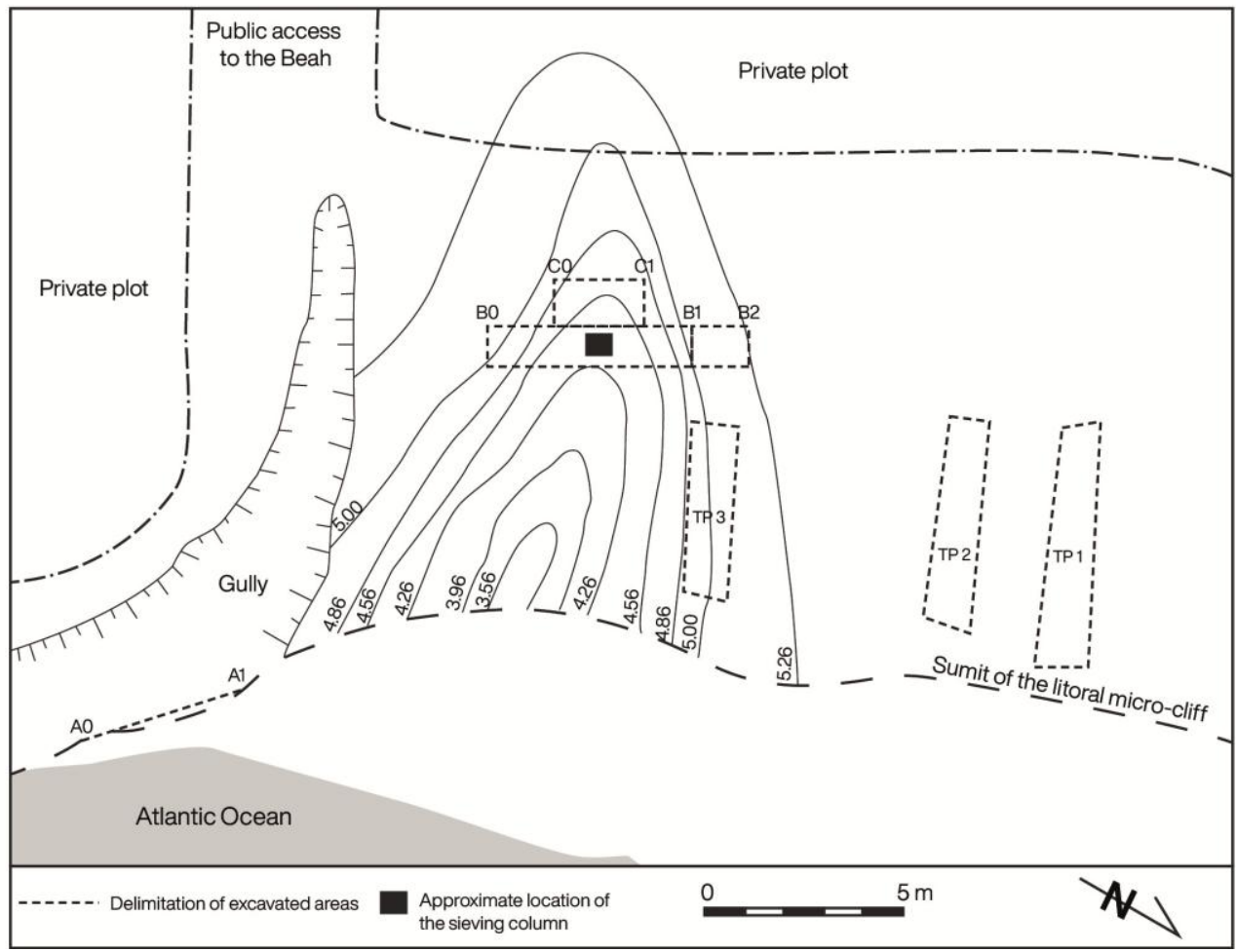

Fig. 1: a) Map of the Guadeloupe Islands with isobaths (-200m) from Münch et al. (2013) indicating the location of the Roseau site. b) Chart of the site with locations of the trenches (A0-A1, B0-B2, and C0-C1), test pits (TP1, TP2, and TP3) and sieving column. 

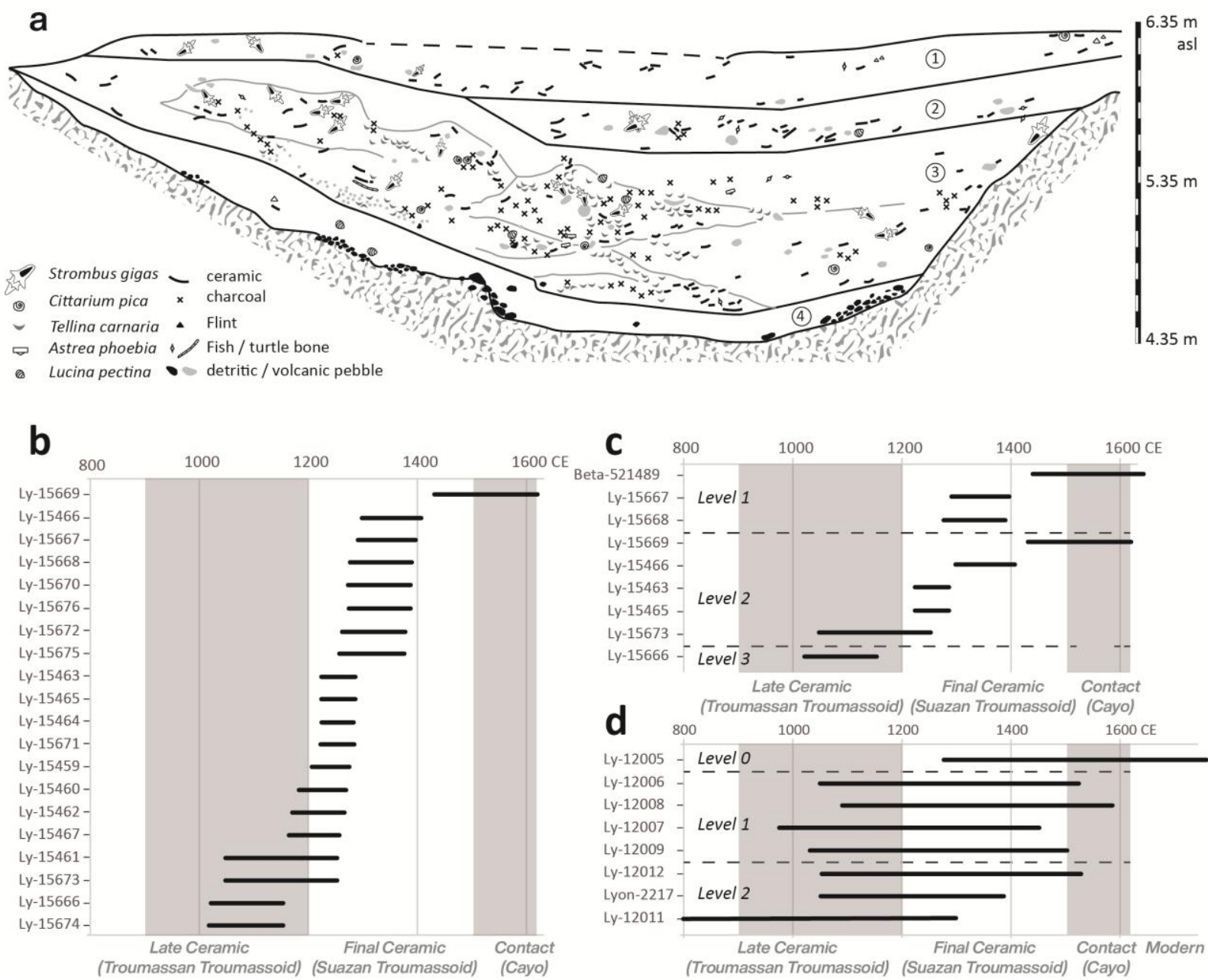

Fig. 2: a) Stratigraphy of the trench B0-B2 (modified from Richard, 2003); b) Radiocarbon dates obtained from rodent teeth from throughout the Roseau assemblage; c) Rodent teeth and human bone (Beta-521489) dates with known stratigraphic origin; d) Previously published and unpublished dates obtained mainly from shell, but also from another type of undefined carbonate (Ly-12009), and human bone (Ly-2217). The labels along the y-axis indicate the laboratory code of each sample. Dates on rodent teeth were calibrated with the Intcal 20 curve, dates on shell and carbonate with the Marine20curve, and dates on human bone with a mixed calibration curve assuming a 33\% contribution of marine carbon for the individual from level 1 (Beta-521489) and 50\% for the specimen from level 2 (Ly-2217). The line represents a confidence interval that includes $95.4 \%$ of the probability distribution. 
a
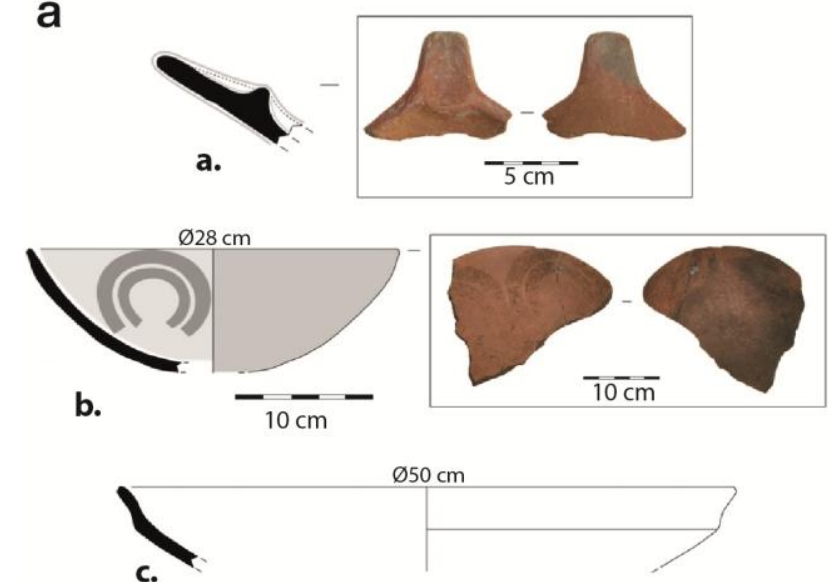

C.

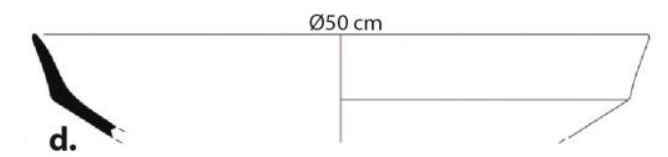

d.
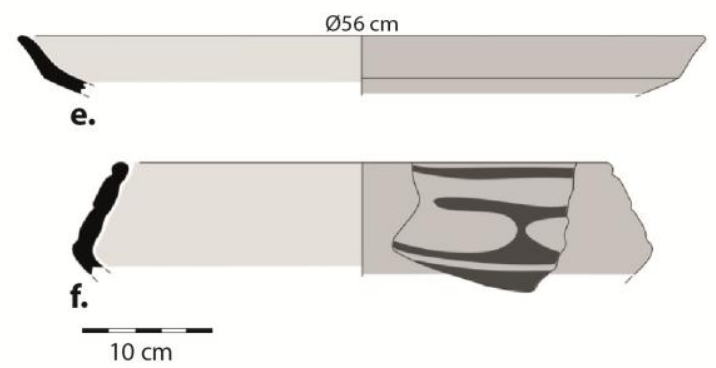

b
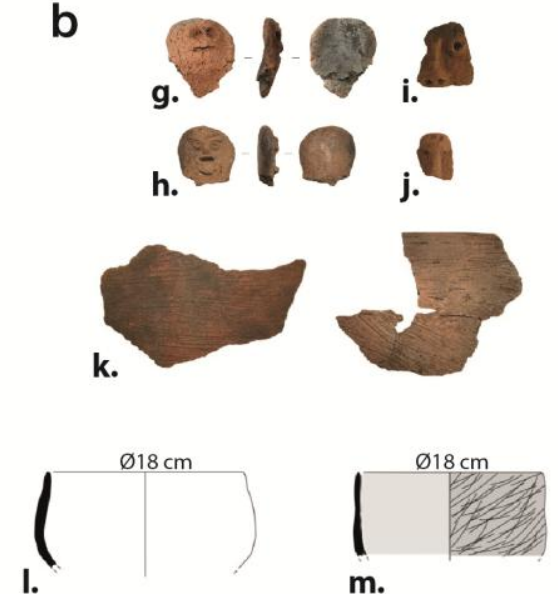

$\varnothing 26 \mathrm{~cm}$

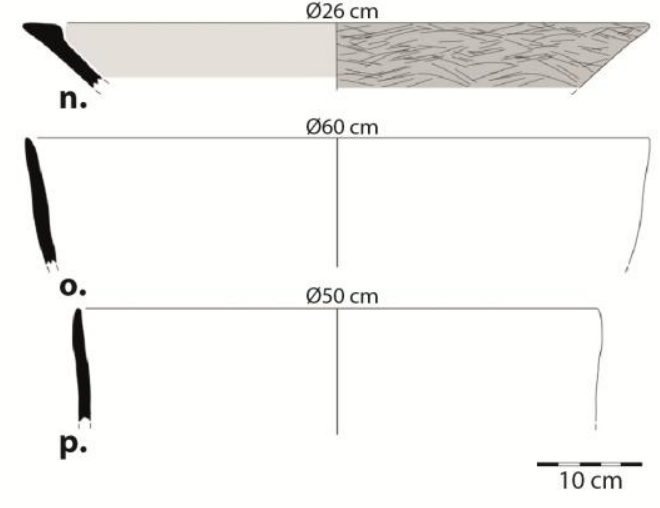

Fig. 3: a) Troumassan Troumassoid ceramic remains: a. Boat-shaped vessel (surface), b. Round bowl with Calivigny painted design (Layer 2), c., d. \& e. Carinated unrestricted vessels (Layer 2), f. Cazuela with broad incisions and red engobe (Layer 3). b) Suazan Troumassoid ceramic remains: g. to j.: Anthropomorphic adornos (Layer 1 and surface), k.: Scratched shards (Layer 2), 1. to p.: Suazan Troumassoid type vessels.
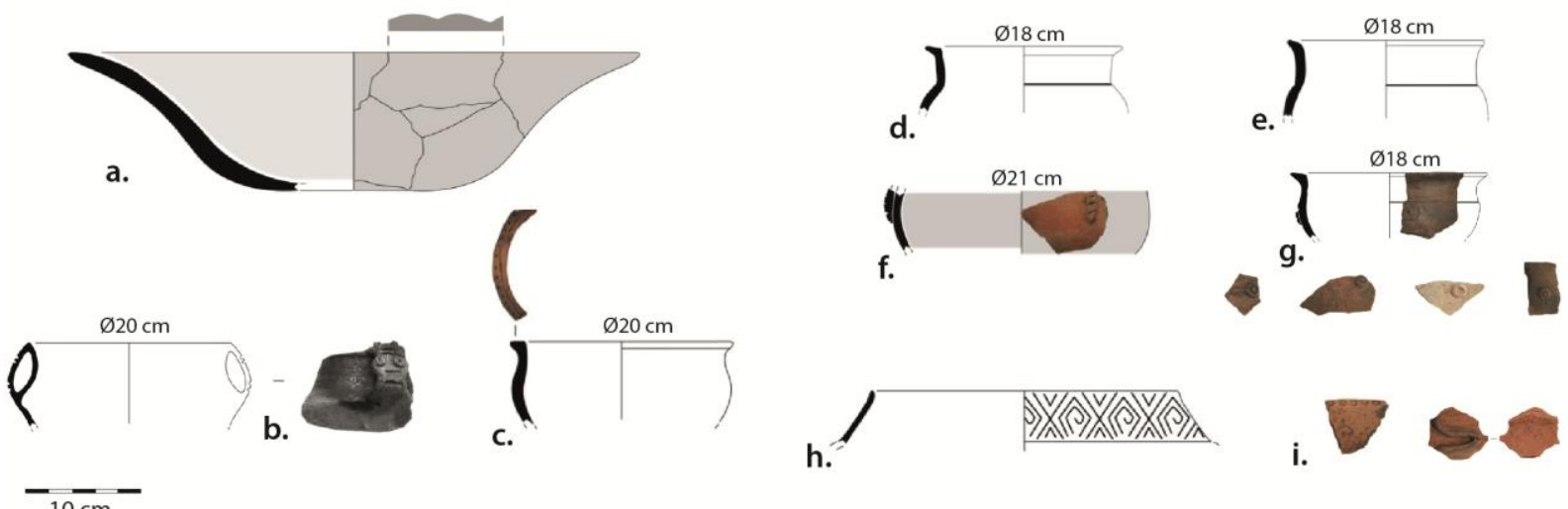

Fig. 4: Cayo style vessel shapes and decorations: a.: Cayo type form 3 (Layer 1), b.: Cayo type form 5 (Layer 1), c.: Bowl with a punctuated design on the lip (Layer 2), d. et e.: Necked jars (Layer 1), f.: Bowl with elongated vertical appliqué nubbins with transversal nicks (Layer 1), g.: Cayo type form 5 and associated typical decorations (Layer 2 and Layer 1), h.: Cayo style jar with inflected contours (Layer 1), i.: Cayo style design (Surface). 
a

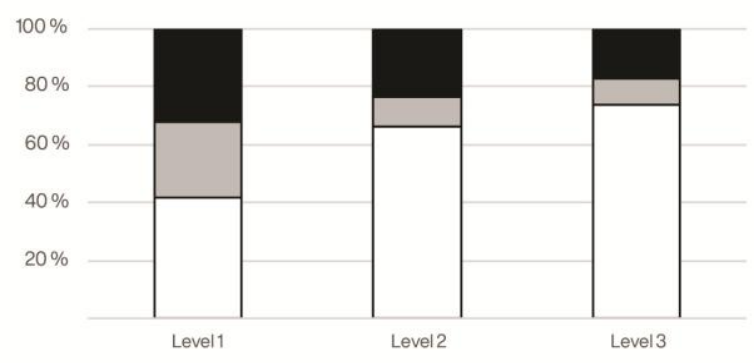

$\square$ Coral Reefs b

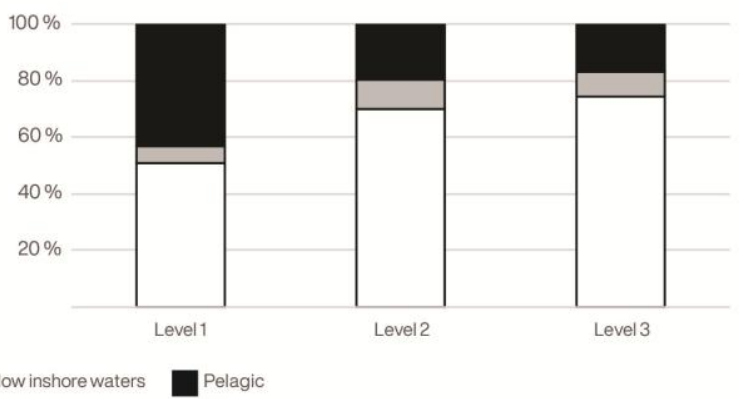

c

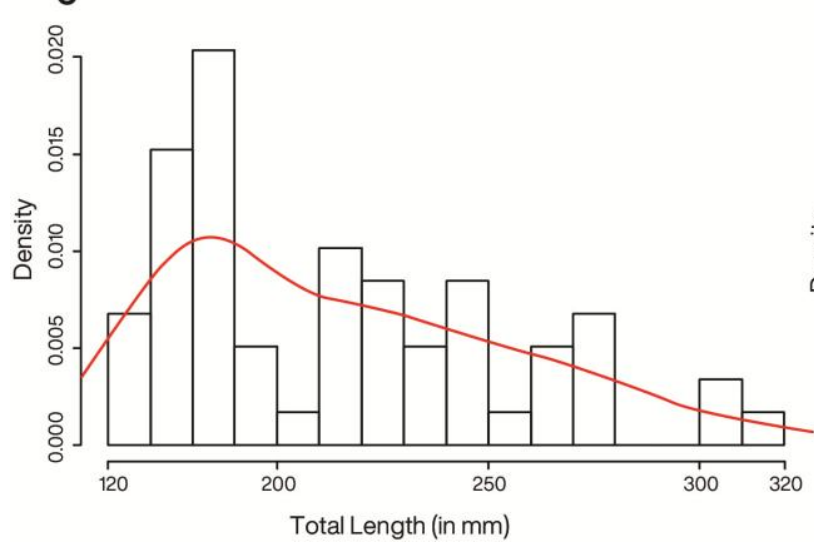

d

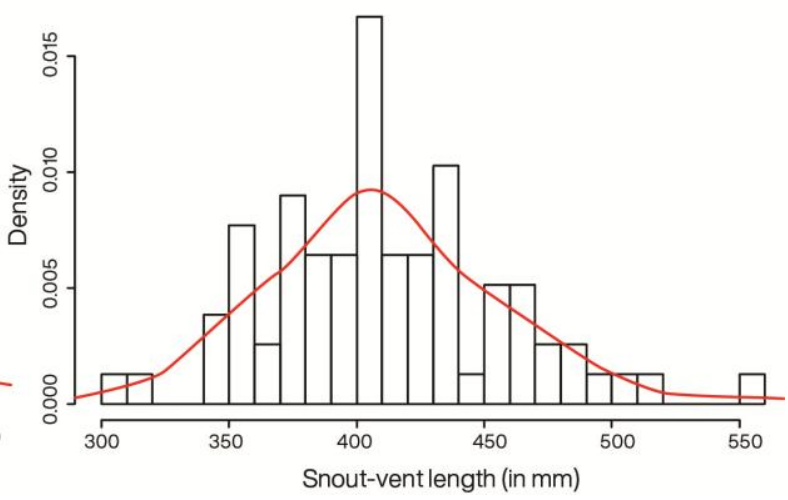

Fig. 5: a) Proportion of the ecological niches represented by the fish remains in the different layers using the total NISP of all identified bone remains; b) Proportion of the ecological niches represented by the fish remains in the different layers using the NISP of the identified bone remains collected through sieving only; c) Distribution of the size of archaeological specimens of Sparisoma sp. (N=38); d) Distribution of the size of archaeological specimens of Iguana $(\mathrm{N}=623)$. 
a
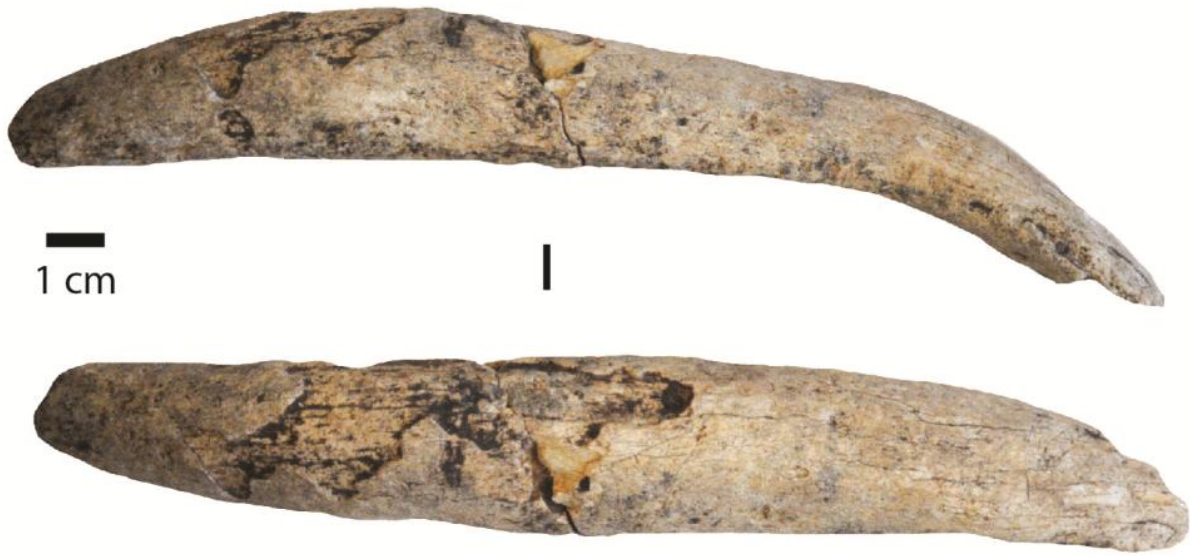

b

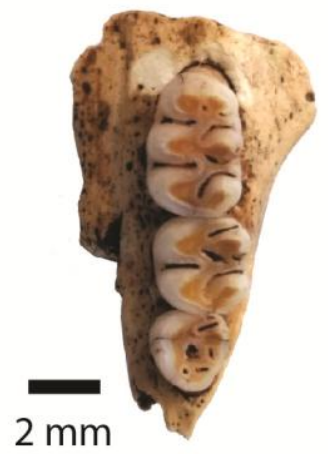

C

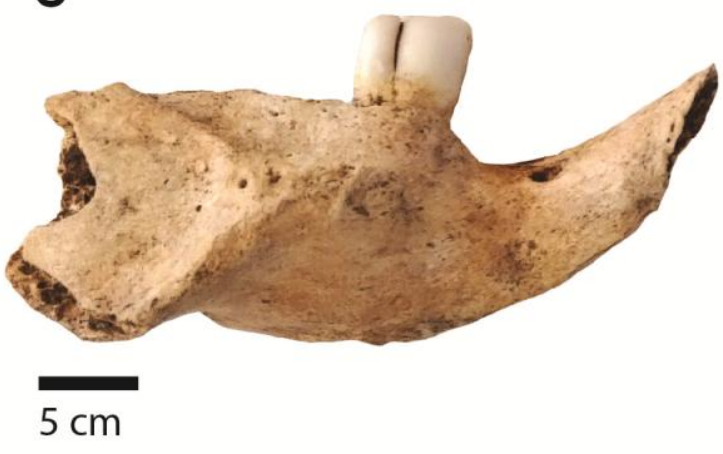

d

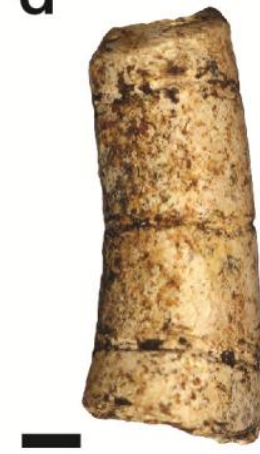

$2 \mathrm{~mm}$

Fig. 6: a) Manatee rib found in the layer 1; b) Right maxilla of Antillomys rayi from layer 2; c) Right mandible of Dasyprocta leporina from layer 1, d) Worked long bone diaphysis of Iguana sp. possibly used as a bead of unknown stratigraphic origin. 